\title{
Joanna ŚCIBEK
}

Uniwersytet w Białymstoku joanna-scibek@wp.pl

\section{"(...) BĘDĘ CI ŚPIEWAL JAK MRĄCE LABĘDZIE (...)" - PORÓWNANIA Z KOMPARANSEM "ANIMALISTYCZNYM" W POEMATACH JULIUSZA SLOWACKIEGO}

Jednym z głównych aktów mentalnych warunkujących poznawanie i konceptualizację rzeczywistości przez człowieka jest porównywanie ${ }^{1}$. Polega ono na zestawieniu „(...) dwu przedmiotów, dwu zjawisk na podstawie jakiejś cechy wspólnej (...)”2. Na płaszczyźnie językowej operacja ta znajduje odzwierciedlenie w postaci „(...) dwuczłonowej konstrukcji semantycznej sprzęgniętej wewnętrznie za pomocą wyrażeń: jak, jako, jak gdyby, na kształt, podobny, niby itd." ${ }^{3}$, zwanej porównaniem. Pełny schemat comparatio obejmuje pięć elementów ${ }^{4}:$ 1) comparandum [Cd], które $\mathrm{w}$ literaturze przedmiotu ${ }^{5}$ funkcjonuje także pod nazwą człon porówny-

1 Więcej o roli porównania w kognicji: L. Krajewski, O gnoseologicznym aspekcie porównania, „Zeszyty Naukowe Wyższej Szkoły Pedagogicznej w Olsztynie. Prace Językoznawcze” 1998, z. II, s. 25-30; A. Kudra, Konceptualizacja porównaniowa. Próba typologii, „Acta Universitatis Lodziensis. Folia Litteraria Polonica" 2009, nr 12, s. 293-299.

2 A. Kulawik, Poetyka. Wstęp do teorii dzieła literackiego, Kraków 1997, s. 95.

3 M. Głowiński i in., Słownik terminów literackich, Wrocław 2005, s. 411.

4 F. Čermák, [za:] M. Bury, Porównania utarte i indywidualne w twórczości T. Konwickiego, „Roczniki Humanistyczne” 1996, t. XLIV, z. 6, s. 37.

5 Zob. m.in.: M.E. Majewska, Porównania w "Urodzie życia” Stefana Żeromskiego (cz. I), „Prace Filologiczne” 2001, t. XLVI, s. 425-426; K. Siekierska, Porównania w "Wojnie chocimskiej" Wacława Potockiego i w "Pamiętnikach" Jana Chryzostoma Paska, "Polonica” 1981, nr VII, s. 234; M. Grzędzielska, Mate i wielkie metafory, „Pamiętnik Literacki” 1971, t. LXII, z. 4, s. 105; T. Dworak, Analiza porównań w "Panu Tadeuszu”, "Pamiętnik Literacki” 1948, t. XXXVIII, s. 265-266; S. Dąbrowski, O pewnej właściwości porównania i metafory, „Pamiętnik Literacki" 1965, t. LVI, z. 3, s. 111-113; M. Pietrzak, Rośliny w porównaniach występujących w "Trylogii", "Język a Kultura" 2001, t. 16, http://www.lingwistyka.uni.wroc.pl/jk/JK-16/ JK16-pietrzak.pdf, s. 170; B. Greszczuk, Z historii konstrukcji porównawczych z "jako", "jakoż" itp., "Język Polski" 1981, t. LXI, s. 42. 
wany lub określany, przedmiot, komparat; 2) relator [R], wyrażony zazwyczaj czasownikiem, 3) comparatum [Ct], inaczej człon porównujący lub określajacy, komparans, wzór porównania - jedyny nieredukowalny składnik struktury porównawczej6; 4) comparator [c] - funktor gramatyczny, wskaźnik (wykładnik) zespolenia, łącznik porównawczy, oraz 5) tertium comparationis [Tc], wspólna cecha motywująca zestawienie, wedle słów S. Dąbrowskiego - „moment styku między członami porównania”7, różnicujący tworzone paralele pod względem bliskości i logiki więzi między odnoszonymi zjawiskami ${ }^{8}$, np.:

„Mnichu! gdy potok lat [Cd] przeminie, / Zdaje się [R] krótkim [Tc] jako [c] przelot konia [Ct], / A jam tak prędko śpieszył się przez błonia" (M, 83)99.

Interpretacja przedmiotu poprzez referencję do innego elementu rzeczywistości może uwydatniać jedną z czterech relacji semantycznych: podobieństwo (w szczególnych sytuacjach także tożsamość), różnicę lub przeciwieństwo ${ }^{10}$.

W badaniach nad porównaniem istota comparatio, jako "figury słowno-wyobrażeniowej" 11 , jest zazwyczaj rozpatrywana w opozycji do metafory. Już w 1948 r. J. Kleiner podkreśla odmienność obu tych kategorii, dotyczącą stopnia zbliżenia zestawianych w obrębie tropu jakości, pisząc o dystansie i „dwu szeregach przedstawieńn” w odniesieniu do konstrukcji porównawczych oraz transformacyjnych właściwościach i jedni, „identyczności (...) przedstawień" $12 \mathrm{w}$ przypadku przenośni. Znaczące dla problemu granic komparacji, choć niewolne od polemiki, okazują się ustalenia teoretyczne Anny Wierzbickiej, która kwestię porównania-metafory rozwiązuje na poziomie struktury głębokiej tych zjawisk językowych, pro-

6 Z. Leszczyński, [za:] M. Bury, dz. cyt., s. 37.

7 S. Dąbrowski, dz. cyt., s. 112.

8 Kryterium to pozwala np. wyodrębnić typ porównań arbitralnych: tamże.

9 W nawiasie podano lokalizację cytatu: tytuł utworu (zob. indeks skrótów na końcu artykułu) oraz stronę, na której znajduje się przytoczony fragment w wydaniu dzieła wskazanym w bibliografii. Kursywą zaznaczono konstrukcje porównawcze z komparansem odwołującym się do świata zwierząt.

10 B. Greszczuk, Konstrukcje porównawcze i ich rozwój w języku polskim, Rzeszów 1988, s. 136.

11 E. Jędrzejko, Znaki ludzkiego losu (O funkcji porównań w prozie Herlinga-Grudzińskiego), "Stylistyka" 1994, t. III, s. 89.

12 J. Kleiner, Z zagadnień metaforyki Mickiewicza i Słowackiego, [w:] tenże, Studia z zakresu teorii literatury, Lublin 1961, s. 132-133. 
ponując dla comparatio następującą formułę interpretacyjną: „,rzekłbyś, że to mogłoby być" 13 , np.:

„Wtem nagle [Dzieduszycki - J. Ś.] jak wąż wzdąt się (...)” (B, 105) = = Wtem nagle Dzieduszycki wzdął się - rzekłbyś, że mógłby to być wąż.

Konstrukcje komparatywne poddaje się wszechstronnej klasyfikacji. W zależności od tego, czy porównanie sygnalizuje relację między dwoma stopniami gradacji: comparatiwem i positiwem lub trzema: superlatiwem, comparatiwem i positiwem, czy też ilustruje związek zachodzący na jednakowym szczeblu gradacji, można mówić o komparacjach gradacyjnych bądź niegradacyjnych ${ }^{14}$. Stopień utrwalenia porównań w języku stanowi kryterium, na podstawie którego wyróżnia się konstrukcje potoczne, skonwencjonalizowane oraz konstrukcje indywidualne, doraźne ${ }^{15}$. Z kolei B. i S. Mikołajczakowie w obszarze komparacji realizowanych w utworze literackim wprowadzają podział na porównania tekstowe (wewnątrztekstowe), w których człon określający przywołuje konkretne realia wykreowanego świata przedstawionego oraz porównania asocjacyjne (kulturowe), oparte na skojarzeniach spoza tekstu, faktycznie organizujące tkankę językową dzieła ${ }^{16}$.

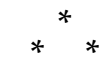

Celem niniejszego artykułu jest charakterystyka pewnego szczególnego typu porównań asocjacyjnych występujących w poematach Juliusza Słowackiego, a mianowicie konstrukcji, w których komparans nawiązuje do świata zwierząt ${ }^{17}$. Materiał leksykalny został wyekscerpowany $\mathrm{z}$ jedenastu utworów Słowackiego powstałych $\mathrm{w}$ erze przedmistycznej

13 A. Wierzbicka, Porównanie - gradacja - metafora, „Pamiętnik Literacki” 1971, t. LXII, z. 4, s. 140. Dla metafory badaczka proponuje natomiast formułę: „rzekłbyś, że to nie..., lecz...". Możliwość znalezienia uniwersalnej formuły interpretacyjnej dla struktury głębokiej porównania wobec bogactwa materiału empirycznego kwestionuje K. Siekierska: dz. cyt., s. 235.

14 B. Greszczuk, Z historii konstrukcji..., s. 42.

15 Zob. np. M. Bury, dz. cyt., s. 38.

16 B. Mikołajczakowa, S. Mikołajczak, Porównania w "Quo vadis" Henryka Sienkiewicza nierocznicowe uwagi w stulecie wydania, „Poznańskie Studia Polonistyczne. Seria Językoznawcza" 1996, t. III, s. 73-74.

17 Z badań wyłączono porównania, w których funkcję wzoru komparacji pełnią stworzenia o mitologicznej, legendarnej albo też literackiej proweniencji. 
(do roku 1842) i liczy 146 jednostek porównawczych ${ }^{18}$. Ich rozkład ilościowy w poszczególnych dziełach wygląda następująco: Arab - 3 porównania, Beniowski (pieśni I-V) - 44, Jan Bielecki - 1, Lambro - 7, Mnich - 6, Ojciec zadżumionych - 4, Podróż do Ziemi Świętej z Neapolu - 18, Poema Piasta Dantyszka - 32, Wacław - 7, W Szwajcarii - 7 oraz Żmija - 17. Analizą objęto struktury niegradacyjne, posiadające formalne wskaźniki komparacji.

W budowanych przez autora Balladyny konstrukcjach porównawczych 'fauna' - obok m.in. 'człowieka', 'przyrody nieożywionej', 'flory', 'śmierci i świata metafizycznego' - należy do najczęściej aktualizowanych pól semantycznych w obrębie comparatum. Tego rodzaju preferencje artystyczne Słowackiego można uznać za wypadkową kilku czynników. Po pierwsze, jak podkreśla L. Krajewski ${ }^{19}$, komparacje $\mathrm{z}$ elementami odsyłającymi do królestwa roślin i zwierząt, zwane porównaniami naturalnymi, mają charakter elementarny i uniwersalny, odwołują się bowiem do pierwotnych wyobrażen, wyrosłych z codziennej obserwacji analitycznej, podczas której natura dostarczała człowiekowi „wzorcowych jakości” na określenie różnych elementów otaczającej go rzeczywistości ${ }^{20}$. Po drugie, porównania „dozwierzęce”, dzięki silnemu ładunkowi ekspresywnemu, właściwościom ukonkretniającym oraz dużej obrazowości, stanowią niezwykle sugestywny środek kształtowania wizji poetyckiej ${ }^{21}$. Istotne jest także osadzenie utworów Słowackiego w nurcie romantycznym, z jego koncepcją natury jako zwierciadła ludzkich emocji i poczynań oraz charakterystycznym zwrotem ku kategorii kolorytu lokalnego. Wreszcie dobór wzoru porównania ujawnia indywidualne upodobania imaginacyjne polskiego wieszcza.

18 Za jednostkę przyjmuje się tutaj także porównania wielokrotne i okresowe.

19 Za R. Ingardenem oraz I. Kurcz: L. Krajewski, dz. cyt., s. 27.

20 Powyższe wnioski na temat roli natury jako podstawowego, uniwersalnego punktu odniesienia dla ludzkiego bycia w świecie padają w kontekście frazeologizmów porównawczych, jednak refleksje te z powodzeniem można rozszerzyć na ogół komparacji ze wzorem roślinnym lub zwierzęcym.

21 Dzięki tym atrybutom porównania oparte na motywach zwierzęcych są z powodzeniem wykorzystywane w poezji polskiej, począwszy od czasów najdawniejszych, aż po współczesność; zob. np. D. Kozaryn, Porównania do zwierząt w "Wizerunku własnym żywota człowieka poczciwego", "Studia Językoznawcze” 2006, nr 5, s. 113-126; U. Sokólska, Leksyka "zwierzęca" jako składnik „comparatum” w porównaniach księdza Jana Twardowskiego, „Białostockie Archiwum Językowe” 2007 , nr 7, s. 153-168. 
Omówienie wskazanych w tytule artykułu tropów stylistycznych ma na celu wzbogacenie dotychczasowego stanu wiedzy na temat idiolektu artystycznego Juliusza Słowackiego.

Konstrukcje komparatywne Słowackiego, w których za punkt odniesienia przyjęto motywy zwierzęce, odznaczają się dużą wariantywnością formalną. Zdecydowana większość porównań to figury proste, oparte na jednej cesze wspólnej (nierzadko towarzyszą jej dodatkowe cechy potencjalne, domyślne $\left.{ }^{22}\right)$ - (a), choć pojawiają się również analogie ufundowane na więcej niż jednej podstawie semantycznej - (b):

a) „Mnie świat szeroki! - Jak złotego gila / Przedała kiedyś Włochom Guślarycha" (B, 156); "A ślad na skale gmachu - jak na belce / Znak skruszonego gniazdeczka jaskótek” (P, 59); „Lazaron / Będzie żył póki ma (...) koszyk, w którym leży jak ostryga" (P, 14); "Jam się nie rzucił jak koń do zawodu, / Ja sam stanąłem przeciwko narodu (...)" (W, 314); „A w drżaccej fali jak srebrne delfiny / Igraty w koło blaski księżycowe" (L, 236).

b) „Nasza czajka szybka, zwrotna, / Choć nie błyszczy w malowidłach; Jak jaskółka czarna, lotna, / Na sitowia leci skrzydłach" (Ż, 166); "Jako żurawi nuta wędrowna / Pieśn przez srebrzyste płynie piołuny, / Miesza się z echem dzika, czarowna (...)" (Ż, 155).

Modelowe porównanie ${ }^{23}$, zawierające wszystkie komponenty, występuje $\mathrm{w}$ analizowanych poematach sporadycznie:

„A zaś nimfa ładna [Swentyna - J.Ś.] / Złożyła złote skrzydełka powoli, / Potem usiadła, ale taka zdradna / Jak wrona, kiedy z wieśniakiem po roli / Chodzi, szykowna i do lotu składna; Widać, że z chtopa drwi, a z psem swawoli" (B, 154).

Zazwyczaj bowiem któryś z elementów, z wyjątkiem comparatum, ulega elipsie. Elementem tym może być:

- człon określany (podmiot zasygnalizowany we wcześniejszych partiach tekstu albo „ja" domyślne, tożsame z narratorem lub osobą poety):

„I [ja, Dantyszek - J.Ś.] wodzę okiem po nieszczęścia światach, / Smutny jak bocian stojący na czatach" (PPD, 288);

22 Zob. T. Dworak, dz. cyt., s. 284.

$23 \mathrm{Cd}: \mathrm{R}: \mathrm{Tc}: \mathrm{c}: \mathrm{Ct}$. 
- relator:

"A ja choć czujny jak zając na zdradę, / Haniebny zwyczaj mam chrapać, gdy jadę" (PPD, 289); "Już chciałem uciąć szablicą te ręce / Krwawe jak szpony orle, lub zwierzęce" (PPD, 299).

Również wspólnota znaczeniowa przedmiotu oraz wzoru porównania bywa wyeksplikowana wprost - zwłaszcza gdy motywacja zestawienia obu zjawisk nie jest oczywista lub gdy następuje wybór jednej spośród kilku domniemanych cech łączących komparat i komparans - bądź też zostaje pozostawiona rekonstrukcji czytelniczej dokonywanej $\mathrm{w}$ trakcie lektury poematów. W funkcji zwerbalizowanego tertium comparationis najczęściej występuje przymiotnik lub imiesłów przymiotnikowy (a) oraz przysłówek (b). Zdarza się, że element ten przyjmuje również inną formę, np. czasownika (c), wyrażenia przyimkowego (d) czy nawet całego zwrotu (e):

a) "Gwar smutny - rzadko pomięszany śmiechem / I tajemniczy jako te odgłosy, / Które wiatr z martwej muszli wydobywa” (L, 218); „I żagiel lotny / Jak skrzydło ptaka / Białymi pióry / Czajkę Kozaka / Niesie..." (Ż, 177);

b) „[Córka - J.Ś.] Przyszła jak ptaszek cicho po kobiercu, / Rzuciła mi się rączkami na szyję (...)” (OZ, 277); „A mi tu trzeba o piekielnym dziwie, / Jak psu po nocy / zaszczekać chrapliwie" (PPD, 265); „(...) gołębie, / (...) / Do spróchniałego wleciały ośrodka, / Skrzydłami siekąc w powietrzu tak silnie, / Jak piskorz kraje wodę lub płotka" (B, 126);

c) „(...) Lub jako gotąb, co w strumieniu pije, / [ukochana - J.Ś.] Do nieba jasnym wzlatywała okiem” (WSz, 290); "(...) waż ['raca' - J.Ś.] leciał paląc się jaskrawie / I syczał (...) i tak jako pawie / Piór płomienistych zaokraglit końce (...) $(\mathrm{B}, 110)$;

d) "Dziewczęta hoże, proste jak badyle, / A ze skrzydłami jak polne motyle" (PPD, 268);

e) „I tak mnie nieśli Boscy aniołowie; / A ja siedziałem jednemu na głowie / Pusząc się duma jak paw na folwarku" (PPD, 264).

Elidowana podstawa porównania zazwyczaj nie sprawia większych trudności interpretacyjnych. $Z$ reguły daje się odtworzyć dzięki kontekstowi, w jakim osadzona jest dana figura lub na bazie wiedzy i doświadczenia czytelnika; czasem proces ten sprowadza się do uzupełniania klisz językowych: 
„(...) Mówiły: a ja płakałem [rzewnie - J.Ś.] jak bobry” (PPD, 267); „Niech trup zazdrości, że ludziom godzina / Uleci sobie [szybko - J.Ś.] jak złote motyle" (PPD, 261); "Czasem jak wilcy trupi [złowrogo, groźnie - J.Ś.] okiem tysnq" (PPD, 273); "A trupek to był: a proszę waszeci! / Fartuszkiem swoim z bielutkiego rąbka / Najpiękniejsza go wzięła [z tkliwościa, czule, delikatnie - J.Ś.] jak gotąka, / I przytuliła" (PPD, 270).

Dotyczy to zwłaszcza komparacji, które cechują się niewielkim stopniem oryginalności. Inaczej dzieje się w przypadku konstrukcji opartych na indywidualnych skojarzeniach. Wymagają one od odbiorcy tekstu rozwiniętych zdolności analitycznych oraz wrażliwości na słowne niuanse:

„Wesołość była ozdobą Polaków, / Lecz już podcięto skrzydła złote ptaków, / To już nie lecą gwiazdom patrzeć w oczy; / A dumne serca teraz robak toczy; / I twarz schylona lepiej dziś przystoi, / Bo nie poleca już rycerze nasi, / Jak ptak, co myśli, że krwiqa słońce zgasi (...)” (PPD, 288); „Dopókiś młody, bawią cię ballady, / Poezja gminna nadzwyczaj zachwyca, / Lubisz w wierszykach chmury, księżyc, gady, / Znajdujesz, że jest jakaś tajemnica / W mgle, w której wiersze brzęcza jak owady / I ubrylantują myśl blaskiem księżyca (...)” (B, 116); „Strofa winna być taktem, nie wędzidłem. / Z niej wszystko wydobyć, zamglić ją tęsknotą, / (...) / Potem ja utkać Arachny robotą, / Potem ulepić z błota, jak pod strycha / Gniazdo jaskótcze przybite do drzewa, / Co w sobie słońcu wschodzacemu śpiewa..." (B, 152).

Przyglądając się szykowi porównań tworzonych przez Słowackiego, często można zaobserwować nietypowe usytuowanie [Tc] po członie określającym lub w pozycji końcowej:

"Cóż po tym? że łby siwe się rozczulą / I znów na piersi zasklepiona ranę, / Jak tby łabędzie spadna zadumane?" (PPD, 276); „W nozdrzach, jak w romu zapalonej czarze, / Płomyk wytryska wielki, błękitnawy, / Czasem jak w nozdrzach arabskiego krwawy" (P, 27); „Kto pałasz kocha i ojczyznę kocha, / Choćby się palił dla niej przez dwa wieki, / I gdzieś jak żuraw odleciał daleki (...)" (PPD, 264).

Podobne odstępstwo od standardowego schematu komparacji staje się udziałem relatora:

„O nie! to Tatar miga od stali, / (...) / Jak wą̇ piersiami / Trawy rozcina (...)" (Ż, 152); „(...) Jak wę̨ża kawały / Rozcięte widma jednym życiem drgały” (L, 238); „Czasem ujrzałeś, że koń piersią porze / Trawy i $z$ trawy jak delfin wychodzi, / Lecz cały na wiatr wyskoczyć nie może" (B, 158).

Charakterystyczne dla romantycznego wieszcza jest także wprowadzanie comparatum na początku porównania, co pozwala uzyskać efekt podniosły, niekiedy celowo przejaskrawiony: 
„(...) A gdy się w drogi zatrzyma półowie, / Jak gołab puszczę za nią skrzydła chyże” (B, 98); "A jako owiec zmoczonych gromadki, / Kiedy przed deszczem schronia się pod gruszę, / Pod smętnym drzewem stały biedne dusze. / A płomień się lat okropnymi rosy, / I sptywał trupom po drżacych ramionach" (PPD, 292).

Analizując konstrukcję wyekscerpowanych tropów stylistycznych, należy wziąć pod uwagę ich poziom organizacji formalnej. Referencja do świata zwierząt może być bowiem realizowana za pomocą samodzielnych porównań, jak również wpisana w nadrzędną strukturę komparatywną. Mowa tu o porównaniach rozbudowanych i spiętrzonych ${ }^{24}$, ujawniających dążenie poety do precyzyjnego, barwnego, wielostronnego opisu wykreowanej rzeczywistości literackiej. Wątki animalistyczne - jako ogniwa w zarysowanych ciągach asocjacyjnych - konstytuują jeden, dwa, a nawet trzy człony określające:

„(...) gałąz (...) / Leciała hucząc głucho i czerwona / Kołysała się nad trupami dwoma, / Jak szatan, co chce duszę brać w ramiona. / Albo orlica z płomieni, takoma / Ciała ludzkiego" (B, 125); "Beniowski nie był to bohater modny, / Co się księżyca tylko karmi blaskiem. / Przypomniał sobie właśnie, że był głodny. / Więc jak astronom gwiazdy wynalazkiem, / Albo poeta ucieszony nowym / Rymem nieznanym i błyskawicowym, / Albo dewotka, gdy grzech jaki stary / Przypomni sobie przed samą spowiedzią, / Albo jak trafne litewskie ogary, / Gdy wpadna razem na łapę niedźwiedzia (...) / Beniowski, ludzi ujrzawszy i pieczeń, / Zsiadł z konia” (B, 151); „I tak się wojsko przez burzany pruło / Jak prąd ogromny sumów lub łososi. / I tak się jako wą̇ żelazny snuło, / Co czasem ogon, czasem łeb podnosi" (B, 158).

Interesującym zabiegiem artystycznym jest bez wątpienia nadanie tertium comparationis kształtu opisowego w postaci odrębnej frazy lub kilku zdań następujących bezpośrednio po właściwej formule porównania. Tego rodzaju chwyt autor Kordiana stosuje wówczas, gdy poprowadzona paralela ciąży ku niejednoznaczności lub wymaga dodatkowego komentarza $\mathrm{z}$ uwagi na niecodzienny charakter prezentowanych skojarzeń:

„Jeżeli książkę położysz przy sobie, / Jeśli szalona ta pieśń z tobą będzie, / Kart nie odwracaj... bo nim spocznę w grobie, / Będę ci spiewał jak mrace łabędzie: / Tak nieśmiertelnym płaczem, że raz jeszcze / Łez brylantowych osypia cie deszcze...” (P, 15); „Słuchaj! ja niegdyśs utopiona w stawie; / Teraz jak mara - jak

24 Nomenklatura zaproponowana przez W. Kupiszewskiego, za: M.E. Majewska, dz. cyt., s. 426 . 
błędne żurawie, / Ciagle ja latam i ciagła mi droga / Od gwiazd do męża, od męża do Boga" (PPD, 300); "A mnichów trzystu sześćdziesięciu pięciu / W błękitnych szatach, z czarnymi brodami, / Snuło się w słońca złotego odbłysku / Jak rój komarów lub mrówki w mrowisku / Lub jak rój pszczelni - bo tak doskonale / W plastrze tynkowym porobił komory, / Tak poświdrował korytarze w skale, / Wiszacym domkom dał takie podpory, / Tyle zapasów nagromadził w doły, / Że Bóg się spyta: "Ludzie wy? czy pszczoły?" (P, 57); "Serce jak muszla wyrzucona z fali, / Petna ślimakiem życie zamknie w sobie; / Cicha - lecz kiedy słońce ja wypali, / Stuchaj! ustyszysz gwar w kamiennym grobie, / Rzekłbyś, że wspomnień napełniona tłumem / Wszystkie zmieszanym rozpowiada szumem" (A, 89).

Jak pokazują dwa ostatnie przykłady, "animalistyczne” porównania Słowackiego mają tendencję do rozrastania się w niezależny, silnie działający na wyobraźnię czytelnika obraz. Uplastycznia on narrację, jednocześnie akcentując moc kreacyjną jednego z najwybitniejszych polskich poetów. Punktem wyjścia dla oryginalnej sceny poetyckiej jest, poza [Tc], przede wszystkim komparans:

„Tak jeśli cię duch Chrystusa nawiedzi, / Będziesz jak bocian, co nigdy nie siada, / Lecz wyciagnąwszy dziób jak włócznię z miedzi, / Prosto wędruje i w gniazdo upada - / Gdzieś na wieśniaczej chacie, zmordowany, / Przebywszy morskie burze i bałwany” (B, 145); „I pokolenie płacze po swym królu; / A jam ostatni z królów pokolenia, / Jako pszczót matka, gdy w umarlym ulu, / Siedzi posępna nad córek grobami, / I sama szuka grobowego cienia" (M, 79).

Natomiast z rozwiniętym członem określanym (i równolegle - określającym) mamy do czynienia w porównaniach homeryckich. Są to figury „(...) paralelne w budowie, dwuczłonowe, ze spójnikiem albo przysłówkiem porównawczym na początku i końcu, np. »jak - tak« (...), które powstają z zestawienia całych obrazów na podstawie podobieństwa cech wspólnych w jedną nową całość (...)"25. Mając pierwowzór w kunsztownych konstrukcjach komparatywnych autorstwa Homera, najznamienitszego z greckich aojdów, stanowią one wyraz najgłębszego wtajemniczenia w sztukę słowa. A. Krupianka dzieli porównania kompozycyjne - bo tak inaczej nazywa się omawiane komparacje - na porównania właściwe oraz porównania niespójne, w których człon pierwszy łączy się z drugim w luźny sposób, bez udziału wykładnika zespolenia jak, dzięki czemu obniżony zostaje patos opisu, a całość nabiera

25 J. Wójtowicz, Struktura porównania homeryckiego, „Meander” 1964, nr 11, s. 475. 
bardziej dyskretnego charakteru ${ }^{26}$. W analizowanych poematach Słowackiego występują oba te typy konstrukcji. Jako przykład porównania niespójnego, dowodzącego maestrii poetyckiej autora Króla-Ducha, można przytoczyć piękny fragment liryczny ukazujący przeżycia i postawę człowieka doświadczonego wielkim nieszczęściem przez analogię do rozbudzonego łabędzia:

„Na cichej wodzie łabędź się poruszyt, / Strzepotał, wody zwierciadlane skruszyt, / Zapetnił caly krag zbudzony nagle, / Otworzył wszystkie puchy, pióra, żagle, / I znów spokojny spogląda wspaniale / Na rozchodzace się kręgami fale. / Tak silne serce posępnie się rzuci, / Kiedy go ze snu jaki grom ocuci, / Porwie się nagle, tłum spokojny zmiesza; / I widzi, jak się przerażona rzesza / Cofa, jak kręgi bladymi ucieka / Od rażonego nieszczęściem człowieka; / To wtenczas duma na pomoc przybędzie, / To wtenczas skrzydła się duszy łabędzie / Całe rozwina przeciw wichrom losu, / To wtenczas serce jak z twardego ciosu; / I tym sie nawet chetpi boleść sroga, / Że miata świadkiem walki - tylko Boga. / I tym się cieszy serce, choćby pękto, / Że zamiast podłych zlitować - przelękło" (W, 302).

Warto podkreślić, iż znaczna część rozpatrywanych konstrukcji komparatywnych wchodzi w bliskie związki z przenośnią. Powinowactwo to polega m.in. na:

a) niedosłownym sensie [Tc], w wyniku czego rodzi się porównanie metaforyczne:

„Krzyczą po zamku, że grafini kona. / Nie dowiedzieć się, z czego, u Greczyna, / Krew w nim zastygła, zimny jak gadzina; / W pochodni światło patrzy obłąkany $(. .$.$) " (W, 309); „O! dajcie mi krwi ojcowskiej, niech bryznę /$ I zwalam twarze dziś białe i ciała! / Bo krew w nich płynie jak w gadzinach biała; / A nie tak ważną jak ojcowie głowę, / Ni takie serca mają bursztynowe" (PPD, 303);

b) sprzężeniu obu tropów i zawieraniu się jednej figury w drugiej:

„(...) ci ludzie żyli / Ze mna przez długie lata trosk, cierpienia / Jak krwi tygrysy - druhy - niewolniki” (L, 225); „Piękny nasz kościół! (...) / Stoi na skale, jego krzyż nad skały / Jak ptak uleciał aż pod nieba stropy” (M, 78); „(...) Dusza wiernych święta, / Niechaj miłością nienawiść odpłaca; / Niech jako muszla srebrzystego tona, / Kiedy pod ciosem chciwych ludzi kona, / Morderce swoje perłami zbogaca" (M, 80);

26 A. Krupianka, Porównania homeryckie w „Panu Tadeuszu” Adama Mickiewicza, [w:] Polszczyzna dawna i wspótczesna, red. C. Łapicz, Torun 1994, s. 65. 
c) kontynuacji obrazu ewokowanego przez jedną z figur:

„(...) Kochanko pierwszych dni! - znów jestem twoim. / Patrzaj! powracam bez serca i sławy, / Jak obłąkany ptak, i u nóg leżę. / O! nie lękaj się ty, że łabędź krwawy / I ma na piersiach rubinowe pierze" (B, 147).

Struktura omawianych tropów stylistycznych jest zróżnicowana także ze względu na rodzaj wskaźnika zespolenia, który wprowadza człon określający z leksyką „zwierzęcą". Dane statystyczne tradycyjnie ujawniają na tym polu dominację liczebną neutralnego stylistycznie zaimka jak (110x). Przyłącza on blisko 75\% wszystkich komparansów „,animalistycznych":

„Sokół żywy - chart twój żywy. / Z toba razem jak z sokołem / Pójdę błądzić nad te niwy / Nad dymiacych chat padotem" (Ż, 161).

Drugim, co do częstości występowania, funktorem gramatycznym jest zaimek jako (18x), stosowany przez poetę zarówno w kontekstach uroczystych, jak i humorystycznych ${ }^{27}$, satyrycznych:

„On, co żył niegdyśs jako salamandra / W ogniu brullotów - dziś spokojny mięszka / W domku glinianym jak domek Ewandra" (P, 31).

Zdecydowanie mniejszą frekwencję mają comparatory złożone:

- jak... tak... (1x), jako... tak... (1x), jak... tak i... (1x), jak... i... (1x) tak jak... tak... (1x), a także pojawiający się w niespójnych porównaniach homeryckich samodzielny wskaźnik tak... (5x), np.:

„Eódź każda wiosłem drugą łódź prześciga / Pod maszt fregaty, gdzie ma skonać Ryga. / I jak chciwe sẹpy albo kruki, / Gdy czują oddech śmierci, tak spłynęli / W bogatych łodziach po morskiej topieli / Z męczarni Greka różne brać nauki" (L, 229);

- tak jak (1x), tak jako (1x), np.:

„O cichy jestem jak wy, o Atrydzi! / Których popioły śpią pod świerszczów strażą. / Ani mię teraz moja małość wstydzi, / Ani się myśli tak jak orly ważă (P, 62).

27 Zob. T. Dworak, dz. cyt., s. 271. 
Czterokrotnie $\mathrm{w}$ badanym materiale spotyka się łączniki porównawcze akcentujące subiektywizm wrażeń i „dystans psychiczny między światem a jednostką ludzką"28 - jakby (1x), jak gdyby (1x), gdyby (1x), niby (1x):

„Beniowski, zgrabnie skoczywszy na strone, / Dał szacht tak plytki koniowi nad głowa, / Że mu z przyciętych uszu dwie czerwone / Trysty fontanny; jak rubin się żarza / W biegu, nadjechat na nie Sawa twarza. / Więc się na białym wydawat rumaku, / Mając zalane oczy krwi wytryskiem, / Jakby delfina miał w złotym czapraku / Pod siodłem, który krew wyrzuca pyskiem" (B, 139); „Struś nie mógł skrzydeł rozwinąć ścigany, / A koń mój leciał jak gdyby miał skrzydła" (A, 89); "Lecz opiszę wam pierwej przewodnika, / Który albańskie rozwiawszy wyloty / Jechat na koniu gdyby motyl złoty” (P, 40); "Trochę skorzystał w sobie jako prawnik, / Trochę skorzystał jak człowiek odarty, / Na którego sam pan sędzia, zastawnik / I regent - niby trzy głodne lamparty / Lub jako muly puszczone na trawnik, / Lub jak na duszę rozsierdzone czarty / Wpadli, ogryźli i na pocieszenie / Rzecz zostawili słodka - doświadczenie" (B, 78).

Trzy razy funkcję wykładnika zespolenia pełni przymiotnik podobny (do), np.:

"Widziałem ludzie do wężów podobne / I zrastające się ich ciała z gadem" (PPD, 302).

Jednostkowo zaś reprezentowana jest w poematach forma czasownikowa $z$ dać się (1x):

„Na samym szczycie, gdzie głazu ułomek, / Postaw forteczkę... i jaskółczy domek... / Niech dym, co mnichów kominami goni, / Framugę sadzy zrobi nad klasztorem, / Niech się to wszystko kiedyś Turkom broni, / Niech teraz będzie spokojne wieczorem / I zda się lekkim pajęczyny włoknem, / W promieniach stońca jasne każdym oknem" (P, 56).

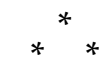

Kategoryzacja semantyczna „animalistycznych” wzorów porównan (zob. Tabela 1) stosowanych przez Słowackiego pokazuje, iż punktem odniesienia dla różnych elementów rzeczywistości poeta czyni najczęściej szeroko rozumiane - zwierzęta i owady (w tym skupiska zwierząt) - 87\%,

28 K. Górski, Kilka uwag o artyzmie językowym Sienkiewicza, „Poradnik Językowy” 1968, z. 3, s. 131. 
oraz ich części ciała - 8\%. Rzadziej pojawiają się w komparansie określenia nazywające siedziby i wytwory zwierzęce (3\%), odgłosy ze świata fauny $(1 \%)$ czy sposoby poruszania się zwierząt (1\%). Językowe nominacje przywoływanych stworzeń to z reguły verba propria, wśród których znaleźć można zarówno hiperonimy (w zależności od szczebla typologii zoologicznej - np. zwierzęta, owady, ptak czy nawet pies w stosunku do brytana i ogarów), jak i hiponimy (np. zając, sokót, piskorz). W nielicznych przypadkach poeta sięga po peryfrazy, np. morska wrona 'mewa', muszla srebrzystego tona 'małż', motyl nie strojny w złoto ni w lazury 'ćma'. Meronimy zwierzęce mają postać konstrukcji z przydawką przymiotną (np. szpony orle, żądła pszczelne, łby łabędzie) lub dopełniaczową (skrzydto ptaka, żadło węża, wieloryba głowa).

Wyraźnie daje się zauważyć faworyzacja motywów ornitologicznych w roli wzoru komparacji (44\%), co potwierdza tezę o „,solarnej, powietrznej wyobraźni" ${ }^{29}$ Słowackiego. Oprócz tego silnie zaznacza się w porównaniach jego imaginacyjna obsesja w stosunku do stworzeń obłych ${ }^{30}$. Bestiariusz złożony z gadów, płazów i stworzeń robakokształtnych obejmuje 19\% wszystkich komparansów „zwierzęcych”.

TABELA 1. Klasyfikacja semantyczna wzorów porównań ${ }^{31}$

\begin{tabular}{|c|c|c|}
\hline Desygnat & Frekwencja & Językowy kształt wzoru porównania \\
\hline \multicolumn{3}{|r|}{ ZWIERZĘTA } \\
\hline zwierzę & $1 \mathrm{x}$ & zwierzeta $[\mathrm{P}]$ \\
\hline \multicolumn{3}{|r|}{ SSAKI LĄDOWE } \\
\hline \multicolumn{3}{|r|}{ dziko żyjące rodzime } \\
\hline bóbr & $1 \mathrm{x}$ & bobry [PPD] \\
\hline wilk & $1 \mathrm{x}$ & wilcy [PPD] \\
\hline zając & $1 \mathrm{x}$ & zajac [PPD] \\
\hline \multicolumn{3}{|r|}{ dziko żyjące egzotyczne } \\
\hline tygrys & $2 x$ & tygrys [Ż], (krwi) tygrysy [L] \\
\hline szakal & $2 x$ & szakal [L; $\mathrm{PPD}]$ \\
\hline
\end{tabular}

29 M. Piwińska, Juliusz Słowacki od duchów, Warszawa 1992, s. 16.

30 Zob. A. Kowalczykowa, Słowacki, Warszawa 1999, s. 265-271.

31 Desygnaty wykazano w indeksie w pojedynczym egzemplarzu, natomiast „animalistyczne" komparansy - w postaci zredukowanej do nazw poszczególnych realiów ze świata fauny ( $w$ tym peryfraz), bez towarzyszących im określeń o charakterze jakościowym. W nawiasie kwadratowym wskazano źródło materiału językowego, zgodnie z przyjętym w artykule sposobem oznaczania dzieł Słowackiego. 


\begin{tabular}{|c|c|c|}
\hline Desygnat & Frekwencja & Językowy kształt wzoru porównania \\
\hline lampart & $1 \mathrm{x}$ & lamparty [B] \\
\hline lew & $1 \mathrm{x}$ & lew [B] \\
\hline nosorożec & $1 \mathrm{x}$ & nosoróg [B] \\
\hline \multicolumn{3}{|r|}{ udomowione } \\
\hline pies & $7 x$ & pies [OZ; PPD; P; B], psy [3xB] \\
\hline brytan & $1 \mathrm{x}$ & brytan $[\dot{Z}]$ \\
\hline ogar & $1 \mathrm{x}$ & ogary [B] \\
\hline koń & $2 x$ & koń $[\mathrm{W} ; \mathrm{B}]$ \\
\hline mul & $1 \mathrm{x}$ & muly [B] \\
\hline \multicolumn{3}{|c|}{ GADY, PŁAZY, ŚLIMAKI, STWORZENIA ROBAKOKSZTAŁTNE } \\
\hline $\begin{array}{l}\text { gad, płaz, zwierzę } \\
\text { pełzające, budzące } \\
\text { wstręt }\end{array}$ & $4 \mathrm{x}$ & gadzina [Ż; W; PPD;P] \\
\hline wąż & $14 x$ & waż $[2 \times \dot{Z} ; \mathrm{OZ} ; \mathrm{W} ; 3 \times \mathrm{PPD} ; \mathrm{P} ; 4 \mathrm{xB}]$, węże [W; PPD] \\
\hline żmija & $2 x$ & żmija [Ż; PPD] \\
\hline pijawka & $2 x$ & pijawka $[2 \times \mathrm{P}]$ \\
\hline salamandra & $1 \mathrm{x}$ & salamandra $[\mathrm{P}]$ \\
\hline$\overline{z ̇ a b a}$ & $1 \mathrm{x}$ & $\dot{z a} a b a$ [B] \\
\hline ropucha & $1 \mathrm{x}$ & ropucha $[\mathrm{B}]$ \\
\hline ślimak & $1 \mathrm{x}$ & ślimak [B] \\
\hline \multicolumn{3}{|r|}{ PTAKI } \\
\hline ptak & $8 \mathrm{x}$ & ptak [M; W, PPD; 2xB], ptaszek [OZ; B], ptaki[JB] \\
\hline gołąb & $10 x$ & $\begin{array}{l}\text { gotab [WSz; 2xPPD, 3xB], gotabek [PPD], } \\
\text { gotębie [WSz; PPD], gotąki [PPD] }\end{array}$ \\
\hline łabędź & $7 x$ & tabędź [W; 2xB], tabędzie [2xWSz; PPD; P] \\
\hline żuraw & $4 x$ & żuraw [2xPPD], żurawie [W; PPD] \\
\hline bocian & $3 x$ & bocian [2xPPD; B] \\
\hline jaskółka & $3 x$ & jaskótka [Ż; PPD], jaskótki [Ż] \\
\hline orzeł & $3 x$ & orzet $[\mathrm{P}]$, orlica $[\mathrm{B}]$, orty $[\mathrm{P}]$ \\
\hline paw & $2 x$ & paw [PPD], pawie [B] \\
\hline jastrząb & $2 x$ & jastrzab [Ż], jastrzabek [B] \\
\hline sokół & $1 \mathrm{x}$ & sokót $[Z \dot{Z}]$ \\
\hline indyk & $1 x$ & ptastwo indyjskie [B] \\
\hline skowronek & $1 \mathrm{x}$ & skowronek [WSz] \\
\hline słowik & $1 \mathrm{x}$ & stowiki $[\mathrm{B}]$ \\
\hline mewa & $1 \mathrm{x}$ & morska wrona $[\dot{Z}]$ \\
\hline szpak & $1 \mathrm{x}$ & szpaki [Ż] \\
\hline sęp & $1 \mathrm{x}$ & sepp [L] \\
\hline kruk & $1 \mathrm{x}$ & kruki [L] \\
\hline wrona & $1 \mathrm{x}$ & wrona [B] \\
\hline gil & $1 \mathrm{x}$ & gil [B] \\
\hline
\end{tabular}




\begin{tabular}{|c|c|c|}
\hline Desygnat & Frekwencja & Językowy kształt wzoru porównania \\
\hline jemiołuszka & $1 \mathrm{x}$ & jemiełuszka [B] \\
\hline struś & $1 \mathrm{x}$ & struś $[\mathrm{M}]$ \\
\hline \multicolumn{3}{|c|}{ RYBY I STWORZENIA WODNE (w tym ssaki) } \\
\hline płotka & $2 x$ & płotka [PPD; B] \\
\hline karaś ozdobny & $1 \mathrm{x}$ & złota rybka [B] \\
\hline piskorz & $1 \mathrm{x}$ & piskorz [B] \\
\hline delfin & $5 x$ & delfin [L; 2xB; WSz], delfiny [L] \\
\hline małż & $1 \mathrm{x}$ & muszla srebrzystego tona $[\mathrm{M}]$ \\
\hline ostryga & $1 \mathrm{x}$ & ostryga $[\mathrm{P}]$ \\
\hline koralowiec & $1 \mathrm{x}$ & koral $[\mathrm{A}]$ \\
\hline \multicolumn{3}{|r|}{ OWADY I PAJĄKI } \\
\hline owady & $1 \mathrm{x}$ & owady [B] \\
\hline motyl & $4 x$ & motyl [P; B], motyle [2xPPD] \\
\hline $\begin{array}{l}\text { pszczoła, } \\
\text { królowa pszczół }\end{array}$ & $2 x$ & pszczót matka $[\mathrm{M}]$ pszczoty $[\mathrm{P}]$ \\
\hline ćma & $1 \mathrm{x}$ & motyl nie strojny w złoto ni w lazury $[\mathrm{M}]$ \\
\hline konik polny & $1 \mathrm{x}$ & polny konik $[\mathrm{P}]$ \\
\hline mrówka & $1 \mathrm{x}$ & mrówki $[\mathrm{P}]$ \\
\hline pająk & $1 \mathrm{x}$ & pajaczek [OZ] \\
\hline \multicolumn{3}{|r|}{ GROMADY ZWIERZĄT } \\
\hline stado & $2 x$ & (gotębi) chmura [WSz], (owiec) gromadki [PPD] \\
\hline ławica & $2 x$ & prad ogromny (sumów) $[\mathrm{B}]$, prąd ogromny (tososi) $[\mathrm{B}]$ \\
\hline rój & $2 x$ & rój (komarów) $[\mathrm{P}]$, rój (pszczelni) $[\mathrm{P}]$ \\
\hline klucz & $1 \mathrm{x}$ & tańcuch (żurawi) [B] \\
\hline szereg & $1 \mathrm{x}$ & nitki (mrówek) [B] \\
\hline \multicolumn{3}{|c|}{ CZĘŚCI CIAŁA ZWIERZĄT } \\
\hline skrzydło & $3 x$ & skrzydto (ptaka) [Ż], skrzydta [A], skrzydła (rybitwy) [Ż] \\
\hline żądło & $2 x$ & żądto (węża) [Ż], żądła (pszczelne) [B] \\
\hline szpon & $2 x$ & szpony (orle) [PPD], szpony (zwierzecce) [PPD] \\
\hline głowa & $2 x$ & tby (tabędzie) [PPD], (wieloryba) głowa [P] \\
\hline muszla & $1 \mathrm{x}$ & muszla [ślimaka-J.Ś.] [A] \\
\hline chrapa & $1 \mathrm{x}$ & nozdrza (arabskiego) [P] \\
\hline fragment ciała & $1 \mathrm{x}$ & (węża) kawaty [L] \\
\hline \multicolumn{3}{|c|}{ SIEDZIBY I WYTWORY ZWIERZĘCE } \\
\hline gniazdo & $3 x$ & $\begin{array}{l}\text { gniazdo (jaskótcze) [B], gniazdeczko (jaskótek) [P], } \\
\text { (jaskótcze) gniazda [Ż] }\end{array}$ \\
\hline pajęczyna & $1 \mathrm{x}$ & pajęczyny włokno $[\mathrm{P}]$ \\
\hline \multicolumn{3}{|c|}{ ODGŁOSY ZE ŚWIATA ZWIERZĄT } \\
\hline klangor & $1 \mathrm{x}$ & (żurawi) nuta wędrowna $[\dot{Z}]$ \\
\hline
\end{tabular}




\begin{tabular}{|c|c|c|}
\hline Desygnat & Frekwencja & Językowy kształt wzoru porównania \\
\hline szum w muszli & $1 \mathrm{x}$ & odgłosy, / Które wiatr z martwej muszli wydobywa [L] \\
\hline \multicolumn{3}{|c|}{ SPOSOBY PORUSZANIA SIĘ ZWIERZĄT } \\
\hline galop & $1 \mathrm{x}$ & przelot (konia) [M] \\
\hline lot & $1 \mathrm{x}$ & lot (ptaka) [B] \\
\hline RAZEM & 154 & \\
\hline
\end{tabular}

Należy zauważyć, iż autor Beniowskiego wykazuje dużą dbałość o różnorodność więzi semantycznych łączących przedmiot i wzór porównania. $\mathrm{W}$ badanym materiale empirycznym podobieństwo między komparatem a komparansem dotyczy wyglądu zestawianych "obiektów" (barwa, kształt, wielkość, cechy szczególne), ich ilości, zachowania, wydawanych dźwięków, sposobu wykonywania czynności i działań, a także implikowanych wyobrażeń. Dzięki tej rozmaitości w językowym obrazie królestwa zwierząt wyłaniającym się $\mathrm{z}$ analizowanych porównań zostały zilustrowane m.in. następujące aspekty zwierzęcej egzystencji ${ }^{32}$ :

a) wygląd zewnętrzny:

„Na masztach różnego koloru bandery, / Tak lekkie, krajane jak skrzydła rybitwy" (Ż, 168); "A twoja siwa się tu rzuca głowa / Jak gołąb biała, lecz w myślach jałowa" (B, 114);

b) rozmiar i liczebność:

„(...) wojska w linii / Jak małe nitki mrówek, a na murze / Rozwijał się dym $\mathrm{z}$ harmat $\mathrm{w}$ białe róże" $(\mathrm{B}, 120)$;

c) wydawane odgłosy:

"Jak śpiewający na niebie skowronek, / Z gór stychać było pustelnika dzwonek" (WSz, 292); "Małe sosenki jako pszczoły brzęcza / Jedwabnym kolcem..." (P VI, 32-33); „Idę, a język mi syczy jak żmija, / Mózg wszystko pali, łamie i zabija, / Boleść, co w sercu, cały świat oskarża (...)" (PPD, 268); (...) Piękny to widok, gdy przed wrogów tłumem / Rozwiną skrzydła na barkach sokole / I jako ptaki głusza skrzydet szumem" (JB, 203);

32 Jest to zmodyfikowany zestaw kategorii semantycznych wyodrębnionych przez W. Wysoczańskiego, budujących językowy obraz zwierząt we frazeologizmach porównawczych; W. Wysoczański, Językowy obraz świata w porównaniach zleksykalizowanych: na materiale wybranych języków, Wrocław 2005, s. 352. 
d) sposób poruszania się:

„Skrwawiony ostem i oczeretem / Czołga się basza jak gadzina” (Ż, 70); „Gdy piorunami się noc smętna zmierzchła, / Wylatywała [głowa - J.Ś.] jak gołą i pierzchła" (PPD, 305);

e) praca:

„Córka! - Ja myśleć nie śmiałem o córce! / (...) / Kiedy zrobiwszy z jedwabiu osnowę, / Około cedru biegała po trawie, / Jak pracowity snując się pajaczek" (OZ, 277);

f) zachowanie:

„Szczeknij z boleści i przeklinaj syna, / Lecz wiedz, że ręka przekleństw wyciagnięta / Nade mna - zwinie się w tęk jak gadzina / I z ramion ci się odkruszy zeschnięta (...)" (P, 65); „A ta wyrwała się z grobu jak mara. / I rozsypała się na niej symara; / Pierzchła jak gołąb, dotknęła mi kości, / Owiała wonią trupa i młodości” (PPD, 297); "Plun w twarz, zawołał, tej bezwstydnej marze, / Która jak szakal tu krew trupia zwietrza" (PPD, 280);

g) zachowanie względem człowieka:

„Czajka ma czucie, wierność brytana, / I tak jak brytan o stopy pana, / Tak się o wodne otarła trzciny" (Ż, 182);

h) zachowanie człowieka względem zwierzęcia:

„Pan regimentarz zaś sam mianowicie, / Który obiecał karmić nas jak ptastwo / Indyjskie, imbir przysyłać, muszkatel, / Cierpi, że buty je dziś obywatel!" (B, 135);

i) środowisko oraz siedziba:

„(...) A ta do wody kryje się jak płotka, / Nie mając innej szaty jak ta woda" (PPD; 268); "Chaty wiszące w parowach sioła / Jako jaskótcze czernieja gniazda... (Ż, 183);

j) emocje, doznania:

„(...) a wódka gdańska / W skórzanej flaszy dźwięk dawała smaczny / I bełkotała ta nimfa szatańska / Właśnie jak gołąb, co z miłości grucha, / Lub poetyczna na Litwie ropucha” (B, 87); „Ach! najszczęśliwsi na ziemi nie wiedzą, / Gdzie duchy skrzydła na ramionach kładą, / Gdzie jak łabędzie zadumane sie$d z q^{\prime \prime}$ (WSz, 288). 
U podstaw znacznej części tropów leżą konwencjonalne asocjacje łączone $\mathrm{z}$ istotami żywymi, których nazwy pojawiają się w członie określającym komparacji. Zgodnie $\mathrm{z}$ funkcjonującą w kulturze polskiej opozycją homo - animal ${ }^{33}$, zwierzę (jako takie) uosabia u Słowackiego sferę antywartości, jest straszne i szkaradne. Stereotypowe rysy mają także konkretni przedstawiciele świata fauny ${ }^{34}$ : ślimak - nosi na grzbiecie swój dom, bóbr - płacze rzewnie, sęp i kruk - wypatrują ścierwa, żmija - syczy złowrogo, motyl - jest delikatny, jego życie trwa krótko, skowronek - śpiewa wesoło, pies - szczeka lub przeraźliwie wyje, wdzięczy się, ginie marnie. W wielu porównaniach leksyka „zwierzęca” stanowi nośnik tradycyjnych znaczeń symbolicznych, słowny emblemat określonych cech i zachowań ludzkich: zając $=$ czujność, paw $=$ duma, konik polny $=$ beztroska, pająk $=$ praca, żuraw $=$ wędrówka, pies $=$ wierność, łapczywość, szakal = śmierć, owce = bezradność itd., np.:

"A między nimi synek niedołężny, / Sędziątko z twarzq zwierzęca kretyna, / Może przekleństwo jakiegoś klienta, / Ubrane w takie ciało jak zwierzęta" (P, 17); „(...) Nasz bohater / Dom swój opuszczał ze starym sługą / (....) / Ach, tak jak później nasz sejmowy krater, / Który wybuchnął wielką, jasną fugą / Z Warszawy - Wisłę przewędrował promem... / I mówi, że jak ślimak wyszedł z domem..." (B, 85); „Ale są życia, co z tej samej przędzy / Wina się, dla nich ten rym i przeklęcie / Niech swoją przyszłość w tej pieśni odkryją! / Niech jak psy patrza na trupa i wyją! (B, 113); „I rzekł: „Sam Bóg ci za wodę zapłaci, / Bo chce pić jak pies, bo ogień mam w łonie” (OZ, 274); „Nie znano jeszcze wówczas Wallenroda / I kończyt jak pies, kto zdrada zaczynał" (B, 102); „Wróciłem sobie jak żuraw z podróży (...)” (PPD, 260); „Lecz wam opiszę pierwej przewodnika, / (...) / Śmiał się jak dziecko, a dzieckiem był prawie, / Spiewat, jak polny konik spiewa w trawie" (P, 40); "(...) Tam jak szakal pilnuje gryzących się szyków" (L, 243).

Kształtując tworzywo swej poezji, Słowacki - rywalizujący o prymat $\mathrm{w}$ literaturze romantycznej - nie poprzestaje jednak na powszechnych skojarzeniach, ale umiejętnie przetwarza wykorzystywaną symbolikę, dokonując inwersji ustalonych znaczeń bądź rozszerzając pole asocjacyjne wyrazów odnoszących się do królestwa fauny o nowe, oryginalne składniki. Niebagatelną rolę $\mathrm{w}$ tych zabiegach odgrywają modyfikujące sensy określenia (niekiedy słusznej długości), którymi autor Balladyny obdarza

33 Zob. U. Sokólska, dz. cyt., s. 158.

34 Na podstawie: S. Skorupka, Słownik frazeologiczny języka polskiego, t. 1 i 2, Warszawa 1985; W. Kopaliński, Słownik symboli, Warszawa 1991; W. Wysoczański, dz. cyt., s. 126-197. 
„animalistyczne" wzory komparacji ${ }^{35}$. To właśnie w porównaniach opartych na indywidualnych konotacjach objawia się swoistość autorskiej wizji świata:

„(...) Może wam pokażę / Pełne piorunów usta, piersi, trzewa? / Może zamilknę jak lew, co poziewa / Patrzac na małość zielonego weęża / I zasnę (...)” (B, 130); „A kiedy strumień lat przeminął lotny, / Został na świecie jak bocian samotny; / A żaden $\mathrm{z}$ druhów we śnie, ni na jawie, / Nie przyjdzie usiąść na gościnnej ławie (...)” (PPD, 284); „O! Polsko! Polsko! Święta! Bogobojna! / Jeżeli kiedy jasna i spokojna / Obrócisz twoje rozwidnione oczy / Na groby nasze, gdzie nas robak toczy; / Gdzie urny prochów pod wierzby wiosenne / Skryły się dumać jak tabędzie senne (...)” (PPD, 305), „I niosę główki mego rodu / Jak pokrwawionych gołąbków dwie pary" (PPD, 274).

Pod piórem wieszcza lew - wbrew obiegowym wyobrażeniom uosabia łagodność, bierność, ospałość. Bocian staje się synonimem nie tylko wędrówki, ale również wytrwałości, smutku i samotności. Na gołębie zestawione z trupimi główkami synów Dantyszka zostają przeniesione sensy związane ze śmiercią, makabrą, ohydą. Widoczna jest skłonność poety do trwałego łączenia znaków „,zwierzęcych” z określoną treścią symboliczną, przykładowo figura łabędzia aż trzykrotnie uaktywnia takie wartości, jak: zaduma, „senność i wieczna melancholia” 36.

$\mathrm{Z}$ drugiej jednak strony Słowacki demonstruje w porównaniach niebywałą zdolność maksymalnego wyzyskania semantyki danego wzoru "animalistycznego", eksponując w kolejnych jego użyciach coraz to inne cechy zwierząt przyjętych za punkt odniesienia dla różnych zjawisk rzeczywistości. Doskonałą egzemplifikację tego typu praktyki stanowi opalizujący znaczeniami wąż, funkcjonujący w twórczości Słowackiego jako jeden ze stałych motywów obrazowania służących do poetyzacji w kategoriach grozy i wstrętu ${ }^{37}$. W analizowanych konstrukcjach komparatywnych negatywny ładunek emocjonalny wpisany $w$ postać kusiciela Ewy to zasługa szeregu przydawanych mu atrybutów, wśród których na pierwszy plan wysuwa się m.in.:

35 Czasem podobną funkcję spełnia komparat, rozbudowany relator lub po prostu kontekst, w jakim osadzone jest dane porównanie.

36 D. Kulczycka, "Jestem jak człowiek, który we śnie lata...": o symbolice ptaków w twórczości Juliusza Słowackiego, Zielona Góra 2004, s. 94.

37 T. Skubalanka, Mickiewicz, Słowacki, Norwid: studia nad językiem i stylem, Lublin 1997, s. 113 . 
- zło, przekleństwo:

„Widziałem, panie, rzecz strasznie ohydną - / Lecz nie mów o tym, bo to tajemnica, / Bo jakby na mnie to poczuli księża, / Gotowi wygnać z kościoła jak węża" (PPD, 261);

- zdrada, obłuda:

"(...) gdzie indziej podobny do węża, / Tu zdrajca panem jest żony i męża" (W, 301);

- skrytość, niebezpieczeństwo, podstęp, dwulicowość:

„Im dalej idę, to coraz mniej zgrai, / Każdy się z męka swoja jak wą̇ tai" (PPD, 298); "Często przebrany z bracią Tatary / Na własne sioła niósłem pożary, / Często przez długie, długie godziny, / Pamiętam, nawet przed dniem wyprawy, / Jak wą̇ ukryty pomiędzy trawy, / Patrząc na słońce leżę dzień cały, / By choć dzień jeden ukraść obłudzie" (Ż, 189);

- marność, podłość:

„(...) Że tutaj zdrajca chodził, dumał, siadał, / Tu się śmiał z Boga, a tutaj łzy ronił; / A tu się w grocie kaskadą zasłonił / Bojąc się słońca, co tę ziemię złoci, / I żył jak węże w zimnie $i$ w wilgoci" (W, 315);

- bojaźń, tchórzostwo:

„A ta rzecz drżąca i zgniła i szara, / To musi serce być jakiegoś cara; / To serce, co jak wąz z tacy umyka, / Musi być z cara, albo z niewolnika, / Bo drży wyjęte z piersi, bo się boi" (PPD, 279);

- oziębłość, nieczułość:

„Stałem się wreszcie jak wą̇̇, gdy ochłodnie. / I przechodziły mi dnie i tygodnie / Bez żadnych bolów, pamiątek, omamień. / Stałem się twardy i zimny jak kamień" (OZ, 282);

- hańba, upokorzenie:

"Gdy dawniej się w rękach i na linie Włocha / Gięłam jak wąż, cóż robiły pany, / Abym mię słowem sczerwienić choć trocha!” (B, 157); „O Polsko! (...) / Jeśli masz z twoja rycerska uroda / Iść między ludy jak wąż, co się wije; / (...) Zostań, czym jesteś - ludzi wielkich prochem!" (B, 82). 
Dzięki takiemu rozwiązaniu porównania Słowackiego, mimo iż niejednokrotnie odsyłają do tych samych elementów świata zwierzęcego, zachowują świeżość i finezję ekspresji.

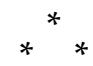

Biorąc pod uwagę treść komparatu, z którym poeta zestawia różne okazy fauny ${ }^{38}$, analizowane konstrukcje porównawcze można przyporządkować do kilku nadrzędnych grup semantyczno-funkcjonalnych. Z uwagi na ograniczoną objętość artykułu szczegółowo omówione zostaną jedynie zespoły najliczniej reprezentowane ${ }^{39}$.

Wyraźnie zaznacza się antropocentryczna natura ${ }^{40}$ wyekscerpowanego materiału empirycznego, bowiem ponad $60 \%$ wszystkich tropów z komponentem "zwierzęcym” w członie porównującym tworzy sugestywny portret człowieka, zarówno w wymiarze indywidualnym, jak i ponadjednostkowym. Obiektem komparacji są bohaterowie wykreowani przez Słowackiego, sam poeta, a także postaci autentyczne żyjące w czasach mu współczesnych. Niewielka część figur mówi natomiast o istocie ludzkiej ujmowanej w perspektywie uniwersalnej.

Charakterystyki, których nośnikiem jest porównanie z komparatem osobowym, dotyczą usposobienia, zachowania, czynności wykonywanych przez człowieka, rzadziej ich przedmiotem staje się wygląd zewnętrzny bohaterów, ich moralność lub ogólnie ludzka dola. Utrzymane mogą być one $\mathrm{w}$ konwencji:

- realistycznej:

„Taj będzie koniec z żałośną Swentyną! / Oj! nalatała się ja po kurhanach! / Oj! nakarmita się gorzka kaliną! / Jak jemiełuszka! (...) (B, 156);

38 Oraz związane $\mathrm{z}$ nimi realia.

39 Poza głównymi typami konstrukcji omówionymi w dalszej części artykułu, w poematach można spotkać także pojedyncze tropy z komparatem nazywającym niematerialne wytwory kultury (uwikłane w kontekst patriotyczny lub poświęcone sztuce uprawiania poezji), porównania dotyczące - szeroko rozumianych - wrażeń słuchowych oraz środki stylistyczne, których przedmiotem są części ciała (ludzka głowa) lub elementy świata metafizycznego, zorientowane na wytworzenie nastroju grozy i efektu makabry.

40 Jest to znamienna właściwość porównań odsyłających do zwierząt, co potwierdzają badania A. Nowakowskiej: „Człowiek jak zwierzę". Sfrazeologizowane porównania doczasownikowe na podstawie "Słownika frazeologicznego języka polskiego", "Język a Kultura" 2003, t. 15, http:// www.lingwistyka.uni.wroc.pl/jk/JK-15/JK15-97-102-nowakowska.pdf, s. 99. 
- groteskowej, humorystycznej (w pierwszym fragmencie jej sygnałem jest forma deminutywna w komparansie, w drugim zaś - odległość kojarzonych w obrębie tropu elementów):

„[Dzieduszycki - J.Ś.] Tak mówiąc teścia przyszłego kolana / Ścisnął pod stołem, i oczy co straszą / Chłopów jak oczy czerwone szatana, / Uczynił cukrem i ponętą ptaszą - / A miał na oczach swoich, jak jastrzabek, / Z powiek wilgotno-czerwonych obrąbek” (B, 104); "Ów pan wspaniałej tuszy - trochę baba / Na twarzy - dziwnej miał zbroję struktury. / Od kołnierza mu szła żelazna sztaba, / Malowanymi natykana pióry. / Rzekłbyś, że rodzi go królowa Saba, / Że z dawnych czasów spadt jak żaba z chmury. / Chociaż się zbroja nam wydaje dzika - / Beniowski poznał zaraz pancernika" (B, 150);

- idealizującej:

"Jakoby Irys, co rzuciwszy koło / Z tęczy, zlatuje na zamglone niwy: / Lekko jak anioł, jak ptaszek wesoło, / Dzieweczka z dębu dała skok straszliwy" (B, 140).

W celach poetyzacyjnych Słowacki tworzy porównania, w których komparansy zawierają nazwy zwierząt budzących pozytywne emocje, łączonych z pięknem, baśniowością czy wyższymi stanami bytu. Budują one wizerunki kobiet-boginek odznaczających się następującymi przymiotami:

- dumą, wdziękiem, dostojeństwem:

"Ale to nie był los panny Anieli. / Chociaż tak piękna jak żadna śmiertelna, / Zbliżyć się ludzie i kochać nie śmieli. / Została dumna i nieskazitelna, / Chodzita jako tabędź lub anieli, / Kołysząc się na giętkiej stopie" (B, 92);

- czystością, nieskazitelnością, ale też ukrytą zmysłowością:

„Ach! ona była jak białe łabędzie, / Była jeziora błękitnego panią" (WSz, 286);

- giętkością i zwinnością ciała:

"Coś do tej główki wpadło i pobiegła, / Biegnąc, jak gdyby była złota rybka, / Która od wędki $z$ dala plusk spostrzegła; / I coraz prędzej leciała, i gibko / Chwiała się, ogniem twarzyczkę zażegła" (B, 111);

- eterycznością, swoistą niebiańskością:

„A ta dzieweczka, by duch ideału, / Stojąc nóżkami na końcu czapraka, / Resztą się ciała - strach przechodzi mrowi! - / Oddała całkiem unieść błękitowi. / I błękit ja wzią tak zrównoważona, / Z rozciągniętymi jako ptak 
raczęta” (B, 140); „Nie wiem, jak sobie jej postać malować? / Czy kiedy przyszła spiącego całować / Jak z rozwartymi skrzydłami gołębie?" (WSz, 295).

Zdarza się, że zestawienie człowieka ze zwierzęciem opiera się na grze słów, czego przykładem jest skojarzenie imienia hetmana kozackiego Żmii z motywującym je apelatywem:

„Któż pójdzie w piekło? ... Patrzcie! sam Żmija - / Jak istna żmija ogień przelata, / I padł do fali, wśród fal się wzbija; / I znów zatonął... (Ż, 186).

Zabieg ów prowadzi do charakterystyki podwójnej - sytuacyjnej, dla której punkt wyjścia stanowi konotacja: „żmija to stworzenie rzucające się zaciekle", oraz permanentnej, wyrosłej z tradycyjnego postrzegania tego gada jako istoty podstępnej, przewrotnej, co znajduje odzwierciedlenie w podwójności czynów bohatera.

Komparacje realizujące wątki „animalistyczne” Słowacki czyni także środkiem egzotyzacji świata przedstawionego. I tak chociażby w opisie baszy tureckiego $\mathrm{w}$ roli wzoru porównania pojawia się tygrys, należący do tego samego co bohater kręgu kulturowego. W ten sposób poeta ilustruje drapieżną, srogą naturę wschodniego dostojnika oraz drzemiące w nim dzikie instynkty. Przedłużeniem tych asocjacji staje się figura jastrzębia:

„(...) Pośród drużyny / Wznosi się wielka klatka ze trzciny, / A w klatce siedzi basza natolski. / (...) a zgraja dzika / Jak na tygrysa patrzy w sitowie, / Plwa mu na czoło, palcem wytyka” (Ż, 186); „Basza jak jastrząb krążył wokoło, / Na różne strony zwijał wędzidłem, / I rzucał czekan, i koniem toczył" (Ż, 193).

Paralele do świata fauny służą niekiedy hiperbolicznej autokreacji samego wieszcza ${ }^{41}$. Chętnie akcentuje on swoje symboliczne powinowactwo z orłem - królem przestworzy, manifestując tym samym przekonanie o własnej potędze, odwadze, geniuszu, a jednocześnie wyrażając tęsknotę za wznoszeniem się na szczyty poetyckiego natchnienia:

"(...) Czy orzeł kiedy myśli o tem, / Że kiedy w zimie słońce zda się nisko, / Mógł o południu natężonym lotem / Dolecieć - patrząc oczyma w ognisko niebieskich krain? (...) / myśl głupia dla świata / Mogła się przyśnić orłowi na skale / Lub temu z ludzi, co jak orzeł lata..." (B, 38).

41 Por. D. Kulczycka, dz. cyt., s. 112-113. 
Dodatkowo w analogiach do królestwa zwierząt znajdują swój refleks deklaracje programowe Słowackiego (swoboda poetycka, wolność wyobraźni):

„Wolę porzucić dym, płomień, pieczywo, / Rycerza, moję szlachtę - a sam w stepy / Jako ognisty kon z rozwiana grzywa, / Jak Ariost, nie jak Homer ide ślepy" (B, 152).

Komparat osobowy może odnosić się nie tylko do jednostki, ale także do zbiorowości (explicite lub implicite). Funkcję wzoru porównania pełnią wówczas najczęściej motywy ornitologiczne lub teriologiczne. Za pomocą tego typu tropów poeta:

- szkicuje sylwetkę Kozaka, „syna stepu”, uwypuklając znamienne jej rysy - nomadyzm, zwinność, gwałtowność, awanturniczość, skłonność do rozboju:

„A tu na morzu Kozak zbłakany, / Gdy się przez czajkę fala przelewa, / Jak morska wrona ze srebrnej piany / Otrzasa skrzydła, na wierżch wypływa; / Byleby w fali znalazł dolara / Lub piastr turecki... (Ż, 172); „Druhy! do wioseł! już dają znaki, / Ażeby iskrą podrażnić działa; / Lecz my pierzchniemy stadem jak szpaki, / Próżno nas będzie kula szukała" (Ż, 178);

- diagnozuje kondycję moralną narodu polskiego (przewartościowanie następuje w obrębie ustalonego symbolu, jakim jest gołąb - synonim czystości, niewinności):

„Jak okrwawione po nocy gołębie, / Kiedy na pole walki pić przyleca; / Nie wiedza same, co piły czym świeca? / Tak i my biedni, ludzie nieobłudni, / Cóżeśmy winni, że krew w naszej studni? / Cóżeśmy winni, że krwia czara tlusta / I krwawe oczy i czerwone usta?" (PPD, 274);

- snuje refleksje historiozoficzne, zapowiadające przyszłe idee genezyjskie (żurawie stają się metaforyczną prefiguracją duchów wiodących):

„(...) Jednak wierzę, / Że ludy płyna jak łańcuch żurawi / W postęp..." (B, 160); „Miłość ojczyzny - o! to słońce świetne / Dla serc, co dumne, sieroce, szlachetne, / Całe się czystym miłościom oddadzą. / Jako żurawie, co łańcuch prowadza, / Świetniejsze serca wylatuja przodem; / Umrą - ich duchy lecą przed narodem, / Ich wrzask, ich imię, ich lament to hasła" (W, 315) ${ }^{42}$.

42 W przykładzie tym wyraz serca pozostaje w stosunku metonimicznym wobec ludzi. 
Szczególnie dosadne okazują się komparacje wykorzystane przez poetę jako narzędzie polemiki z nieprzychylną mu romantyczną krytyką literacką:

„Był czas, żem lękał się pospolitości, / Jako święconej duch się lęka wody; / Lecz teraz często schodzę z wysokości / Dla własnej sławy, pokoju, wygody; / Krytykom jak psom rzucam kilka kości. / Gryzą, lecz przyjdzie czas, że te Herody, / Przez których teraz moje dzieci giną, / Będę gdzieś w piekle gryzł jak Ugolino" (B, 117); „(...) krytyka owa, która co rok / Tyle wad w moich utworach wytyka / Jako ostrowidz lub jako nosoróg, / Bo widzi ostro i rogiem przenika; / Szczęśliwa - gdybym dbał i był gorący, / I włożył imię jej w poemat drwiący" $(B, 118)$.

Swą siłę oddziaływania zawdzięczają one pejoratywnym konotacjom wnoszonym przez wzór porównania: nosorożec kojarzy się z zadawaniem ran, sprawianiem bólu, natarciem, natomiast psy ucieleśniają wszystko to, co w człowieku niskie, podłe, nikczemne.

Następny zbiór porównań z komparansem „zwierzęcym” stanowią tropy, które ukazują bogate życie wewnętrzne istoty ludzkiej. Są wśród nich porównania mające za przedmiot człowieka oraz jego serce (występujące jako metonimia podmiotu doznającego), a także animizujące konstrukcje z komparatem abstrakcyjnym. Pierwszy charakteryzowany przez nie obszar to sfera uczuciowa eksperiencera. Interpretacji przez pryzmat świata zwierząt podlegają zarówno pozytywne, jak i negatywne treści emocjonalne, np. euforia miłosna romantycznego kochanka z poematu W Szwajcarii, poczucie winy nieszczęsnego Wacława, ból rodzicielski Piasta Dantyszka po stracie dzieci, cierpienie i autodestrukcyjny pęd bajronicznego renegata z Mnicha czy swoista martwota uczuciowa sadystycznego Araba:

„Wszystkie uczucia gwałtownymi loty / Na serce spadly, jak gołębi chmura / Pić łzy i białe w nim obmywać pióra, / Aby się czyste rozlecieć po niebie..." (WSz, 286); „Niech tylko wprzódy nie splami zgryzota / Duszy, co jak ptak się w sidtach miota” (W, 297); "Dobrze! nie będę was ptakać, o! dziatki! / Ani jak ojciec ani tak jak matki; / Lecz jak jaskółka jaka nieszczęśliwa, / Co puste gniazdo skrzydłami nakrywa; / I o swych dzieciach jak o żywych roi, / I pod skrzydła się własne zajrzeć boi" (PPD, 277); „Motyl nie strojny w złoto ni w lazury, / Ledwo z jedwabnej dziś zmartwychwstał truny, / I znów tak blisko pogrzebu świecznika. / Skrzydła czernieja jak zmartych całuny, / I ma na skrzydłach pisany gniew Boży, / Co mu tak cięży, że je w ogniu pali... / Tak dziki Arab, gdy się los rozsroży, / W dzień jest spokojny i zattumi jęki; / Lecz gdy noc ciemne przywdzieje zasłony, / Lśni przed nim jasność samobójczej stali, / Patrzy 
posepny na niebios sklepienia, / Twarz ma pobladła i wzrok zapalony, / I widać drżenie wstrzymywanej ręki; / Silne jak drżenie głodu lub pragnienia" (M, 77); "Może gdzie zemsta to serce obudzi, / Już skamieniałe wśród kamiennych ludzi. / Tak koral niegdyś żył pod morska woda, / Nieraz się smucił przewidując burze; / Gdy słońce w niebios błysnęło lazurze, / Koral jak majtek cieszył się pogoda; / Ale zerwany wichrami jesieni, / Skamieniał błądząc wśród zimnych kamieni" (A, 87).

Na drugi „blok” tematyczny składają się figury obrazujące stany duchowo-intelektualne, których doświadcza autor Mazepy, na czele z twórczym ożywieniem poetyckim, np.:

„I ducha weny lekkiego nie płoszę, / Który na mózgu jak motyl na róży / Usiądzie - aż się kwiat listkami zmruży, / A potem nagle odemknie swe tono / Świeże i jasne - i na okolice / Rozeszle wonie, co wszystko pochtona” (B, 84); "Tymczasem z szumów żaglowych i waru / Myśli zhukanych jest harmonia dzika, / Którą ja lubię, że tak pełna gwaru, / Że czasem jak wą̇̇ pośród ruin syka, / Czasem podobna do aniołów swaru (...)" (B, 137).

Prezentacja ludzkiego wnętrza $\mathrm{w}$ relacji do pierwiastka zwierzęcego nie tylko potęguje ekspresję ewokowanej wizji, ale też umożliwia opis złożonych procesów psychicznych, trudnych do zwerbalizowania w sposób konwencjonalny.

Wzorca w świecie fauny Słowacki upatruje również dla wytworów kultury materialnej człowieka (architektura - kościoły, klasztory, domostwa kozackie; pojazdy, broń, trunki i in). Porównania z komparatem przedmiotowym stanowią ok. 13\% wszystkich analizowanych tropów. Daje w nich o sobie znać bardzo dobrze rozwinięty zmysł obserwacyjny polskiego wieszcza, dzięki któremu kanwą dla oryginalnych obrazów poetyckich czyni on rozmaite elementy życia codziennego. W analizowanych dziełach są to przede wszystkim łodzie, statki i militaria:

„A łódź, jak delfin w wodzie rozigrana, / Czasem tonęła w odmęt lazurowy, / Równa powierżchni morza, tak że piana / Żagiel srebrzyła; czasem statek złoty / Po wierżchu fali szedł ptasimi loty (...)" (L, 230); „A jako z płaskiej wieloryba glowy, / W niebo srebrzyste tryskaja fontanny, / Tak spod okrętu młyńskim bita kołem / Wytryska piana, a dym leci czołem” (P, 17). „Miecz straszny Żmii jak żadło węża / Krwi wroga szuka i krwia się poi" (Ż, 179); „I w tej girlandzie niby z róż śmiertelnych / Stało miasteczko w powietrznych błękitach, / Wyrzucające blysk, do żądet pszczelnych / Podobny (...) (B, 120); „Tam jakiś starzec stanął na okopach, (...) I działa jak psy legły mu przy stopach; / On je pogładził i szczęknęły głucho. / Kule gruchnęły po moskiewskich chłopach" (B, 120); „Wrony - czajek przyjaciółki, / Co śmierć kraczą asawule, / Kiedy kule / Jak jaskótki / Nad czajkami po przestworzu / Leca chmura czarną" (Ż, 181). 
Przytoczone porównania dynamizują narrację. W obrębie komparacji batalistycznych niezwykłe uwikłanie semantyczne można zaobserwować w przypadku jaskółki, uważanej powszechnie za znak nadziei i zmartwychwstania, tu skojarzonej z atakiem i śmiercią ${ }^{43}$.

Kolejną, choć niewielką - bo liczącą jedynie 13 tropów (ok. 9\%) grupę tworzą porównania rejestrujące analogie pomiędzy różnymi zjawiskami natury, np.:

„Czy ogień za nim jak pies wierny biegnie?" (P, 35).

Jeśli chodzi o przyrodę ożywioną, najciekawsze figury porównawcze koncentrują się wokół konia, stanowiącego - zwłaszcza w powieściach poetyckich - nieodłączny składnik kreacji romantycznego bohatera. Środki te akcentują niezwykłą szybkość zwierzęcia:

„Lecz koń mi został, i biegł przez pustynie, / Koń, który myśli Araba przenika. / Jak struś na stepach, gdy skrzydła rozwinie, / Ledwie się ziemi stopami dotyka; / I grzywa konia z wiatrami igrała” (M, 76-77); "(...) zagrzawszy rumaka, / Rzuciła w galop taki pełny szału, / Że galop konia był jako lot ptaka" (B, 140).

Natomiast motywy animalistyczne jako punkt odniesienia dla przyrody nieożywionej pojawiają się chociażby $\mathrm{w}$ deskrypcyjnych porównaniach pejzażowych:

„Poszedłem za nią przez góry, doliny, / I szliśmy razem u stóp tej lawiny, / Gdzie śnieg przybiega aż do stóp człowieka / Spłaszczona płetwa jak delfin olbrzymi; / Para mu z nozdrza srebrzystego dymi, / A Rodan z paszczy błękitnej ucieka" (WSz, 285).

Ożywienie generowane $\mathrm{w}$ następstwie komparacji staje się sygnałem subiektywizacji krajobrazu, aktywnego współuczestnictwa natury w przeżyciach bohaterów ${ }^{44}$.

Tworzone przez Słowackiego konstrukcje komparatywne, w których człon określający zawiera referencję do królestwa zwierząt, to materiał niejednorodny (zarówno pod względem struktury formalnej, jak i semantyki), odznaczający się dużą funkcjonalnością. Komparacje te odwołują się

43 Por. D. Kulczyka, dz. cyt., s. 224.

44 Zob. T. Skubalanka, Nad tekstem „W Szwajcarii”. Uwagi o genezie stylistycznej utworu, „Annales Universitatis Mariae Curie-Skłodowska” 1984, vol. II, z. 7, s. 142. 
do faktycznej wiedzy przyrodniczej autora i czytelnika, obecnych w kulturze polskiej stereotypów związanych z konkretnymi zwierzętami, a także do indywidualnych wyobrażeń poety. Antropocentryczny charakter omawianych tropów dowodzi postrzegania przez Słowackiego człowieka i natury $\mathrm{w}$ perspektywie holistycznej.

\section{WYKAZ SKRÓTÓW TYTUŁÓW DZIEŁ JULIUSZA SŁOWACKIEGO}
A $-A r a b$
B - Beniowski (pieśni I-V)
P - Podróż do Ziemi Świętej z Neapolu
JB - Jan Bielecki
PPD - Poema Piasta Dantyszka
L $\quad$ - Lambro
W - Wactaw
M - Mnich
$\mathrm{OZ}$ - Ojciec zadżumionych
WSz - W Szwajcarii
$\dot{Z} \quad-\dot{Z} m i j a$

\section{ŹRÓDŁA}

Słowacki J., Arab, [w:] tenże, Powieści poetyckie, Wrocław 1987, s. 85-93.

Słowacki J., Beniowski (pieśni I-V), [w:] tenże, Dzieła wybrane, t. 2, Wrocław 1989, s. 75-163.

Słowacki J., Jan Bielecki, [w:] tenże, Dzieła wybrane, t. 1, Wrocław 1989, s. 199-215.

Słowacki J., Lambro, [w:] tenże, Dzieła wybrane, t. 1, Wrocław 1989, s. 217-258.

Słowacki J., Mnich, [w:] tenże, Powieści poetyckie, Wrocław 1987, s. 71-84.

Słowacki J., Ojciec zadżumionych, [w:] tenże, Dzieła wybrane, t. 1, Wrocław 1989, s. 269-283.

Słowacki J., Podróż do Ziemi Świętej z Neapolu, [w:] tenże, Dzieła wybrane, t. 2, Wrocław 1989, s. 5-74.

Słowacki J., Poema Piasta Dantyszka, [w:] tenże, Dzieła wybrane, t. 1, Warszawa 1983, s. 255-309.

Słowacki J., Wacław, [w:] tenże, Dzieła wybrane, t. 1, Wrocław 1989, s. 296-323.

Słowacki J., W Szwajcarii, [w:] tenże, Dzieła wybrane, t. 1, Wrocław 1989, s. 284-295.

Słowacki J., Żmija, [w:] tenże, Dzieła wybrane, t. 1, Wrocław 1989, s. 146-198.

\section{LITERATURA}

Bury M., Porównania utarte i indywidualne w twórczości T. Konwickiego, „Roczniki Humanistyczne" 1996, t. XLIV, z. 6, s. 37-58.

Dąbrowski S., O pewnej właściwości porównania i metafory, „Pamiętnik Literacki” 1965 , z. 3, s. 105-124.

Dworak T., Analiza porównań w „Panu Tadeuszu”, „Pamiętnik Literacki” 1948, t. XXXVIII, s. 265-297. 
Głowiński M. i in., Słownik terminów literackich, Wrocław 2005.

Górski K., Kilka uwag o artyzmie językowym Sienkiewicza, „Poradnik Językowy” 1968 , z. 3, s. 120-134.

Greszczuk B., Konstrukcje porównawcze i ich rozwój w języku polskim, Rzeszów 1988.

Greszczuk B., Z historii konstrukcji porównawczych z "jako", "jakoż" itp., "Język Polski" 1981, t. LXI, s. 42-53.

Grzędzielska M., Małe i wielkie metafory, „Pamiętnik Literacki” 1971, t. LXII, z. 4, s. 97-111.

Jędrzejko E., Znaki ludzkiego losu (O funkcji porównań w prozie Herlinga-Grudzińskiego), "Stylistyka” 1994, t. III, s. 88-106.

Kleiner J., Z zagadnień metaforyki Mickiewicza i Słowackiego, [w:] tenże, Studia z zakresu teorii literatury, Lublin 1961.

Kopaliński W., Słownik symboli, Warszawa 1991.

Kowalczykowa A., Słowacki, Warszawa 1999.

Kozaryn D., Porównania do zwierząt w "Wizerunku własnym żywota człowieka poczciwego", "Studia Językoznawcze” 2006, nr 5, s. 113-126.

Krajewski L., O gnoseologicznym aspekcie porównania, "Zeszyty Naukowe Wyższej Szkoły Pedagogicznej w Olsztynie. Prace Językoznawcze” 1998, z. II, s. 25-30.

Krupianka A., Porównania homeryckie w "Panu Tadeuszu” Adama Mickiewicza, [w:] Polszczyzna dawna i wspótczesna, red. C. Łapicz, Torun 1994, s. 61-68.

Kudra A., Konceptualizacja porównaniowa, „Acta Universitatis Lodziensis. Folia Litteraria Polonica" 2009, nr 12, s. 293-299.

Kulawik A., Poetyka. Wstęp do teorii dzieła literackiego, Kraków 1997.

Kulczycka D., "Jestem jak człowiek, który we śnie lata...": o symbolice ptaków w twórczości Juliusza Słowackiego, Zielona Góra 2004.

Majewska M.E., Porównania w „Urodzie życia” Stefana Żeromskiego (cz. I), „Prace Filologiczne" 2001, t. XLVI, s. 425-441.

Mikołajczakowa B., Mikołajczak S., Porównania w "Quo vadis" Henryka Sienkiewicza - nierocznicowe uwagi w stulecie wydania, "Poznańskie Studia Polonistyczne. Seria Językoznawcza" 1996, t. III, s. 67-90.

Nowakowska A., "Człowiek jak zwierzę". Sfrazeologizowane porównania doczasownikowe na podstawie "Słownika frazeologicznego języka polskiego", „Język a Kultura" 2003, t. 15, http://www.lingwistyka.uni.wroc.pl/jk/JK-15/JK15-97102-nowakowska.pdf, s. 97-102.

Pietrzak M., Rośliny w porównaniach występujących w "Trylogii”, "Język a Kultura” 2001, t. 16, http://www.lingwistyka.uni.wroc.pl/jk/JK-16/JK16-pietrzak.pdf, s. 170.

Piwińska M., Juliusz Słowacki od duchów, Warszawa 1992.

Siekierska K., Porównania w "Wojnie chocimskiej” Wacława Potockiego i w "Pamiętnikach” Jana Chryzostoma Paska, "Polonica” 1981, nr VII, s. 233-254.

Skorupka S., Słownik frazeologiczny języka polskiego, t. 1 i 2, Warszawa 1985. 
Skubalanka T., Mickiewicz, Stowacki, Norwid: studia nad językiem i stylem, Lublin 1997.

Skubalanka T., Nad tekstem "W Szwajcarii”. Uwagi o genezie stylistycznej utworu, „Annales Universitatis Mariae Curie-Skłodowska” 1984, vol. II, z. 7, s. 129-153 .

Sokólska U., Leksyka "zwierzęca" jako składnik „comparatum" w porównaniach księdza Jana Twardowskiego, „Białostockie Archiwum Językowe” 2007, nr 7, s. $153-168$.

Wierzbicka A., Porównanie - gradacja - metafora, „Pamiętnik Literacki” 1971, t. LXII, z. 4, s. 127-147.

Wójtowicz J., Struktura porównania homeryckiego, „Meander” 1964, nr 11, s. 475-489 .

Wysoczański W., Językowy obraz świata w porównaniach zleksykalizowanych: na materiale wybranych języków, Wrocław 2005.

\section{“(...) I WILL SING FOR YOU LIKE DYING SWANS (...)” - COMPARISONS WITH "ANIMALISTIC" COMPARANS IN JULIUSZ SLOWACKI'S POEMS}

\section{Summary}

A purpose of the article is to provide characteristics of comparisons appearing in Juliusz Słowacki's poems exemplified by the constructions where comparans refers to the world of animals. Lexical material has been excerpted from eleven works written by J. Słowacki in the pre-mystic period. They include the following poems: Arab, Beniowski (songs I-V), Jan Bielecki, Lambro, Mnich, Ojciec zadżumionych, Podróż do Ziemi Świętej z Neapolu, Poema Piasta Dantyszka, Wacław, W Szwajcarii and Żmija. Non-gradation comparative structures possessing standard comparison indicators have been analyzed. The article mainly focused on: 1) discussing a formal shape of studied constructions, 2) semantic classification of comparans contained in comparisons referring us to the animal kingdom, 3) emphasizing multitude of "animal" lexis connotations used by the poet, 4) discussing basic subject areas the excerpted comparisons belong to with regard to the meaning of a descriptive chunk, and 5) the most important functions of these clues. It has been established that the analyzed comparative constructions have an explicitly anthropocentric character since they, most of all, serve a suggestive illustration of a human's psycho-physical condition.

Key words: a comparison, an animal, a bird, a style, Juliusz Słowacki 